
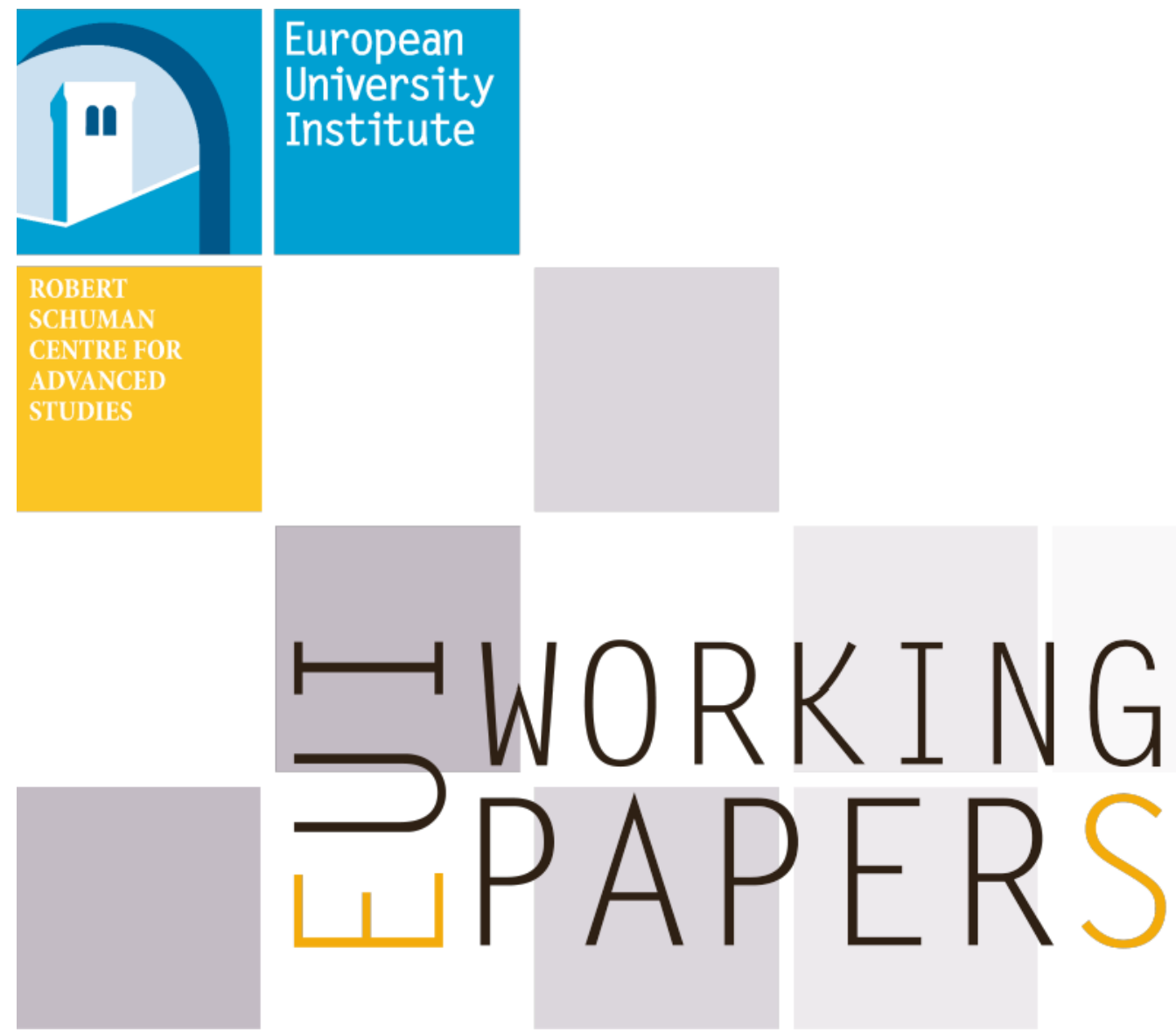

RSCAS 2017/39

Robert Schuman Centre for Advanced Studies Global Governance Programme-274

Services Input Intensity and US Manufacturing Employment. Responses to the China Shock

Omar Bamieh, Matteo Fiorini, Bernard Hoekman, Adam Jakubik 

European University Institute

Robert Schuman Centre for Advanced Studies

Global Governance Programme

Services Input Intensity and US Manufacturing Employment Responses to the China Shock

Omar Bamieh, Matteo Fiorini, Bernard Hoekman, Adam Jakubik

EUI Working Paper RSCAS 2017/39 
This text may be downloaded only for personal research purposes. Additional reproduction for other purposes, whether in hard copies or electronically, requires the consent of the author(s), editor(s). If cited or quoted, reference should be made to the full name of the author(s), editor(s), the title, the working paper, or other series, the year and the publisher.

ISSN 1028-3625

(C) Omar Bamieh, Matteo Fiorini, Bernard Hoekman, Adam Jakubik, 2017

Printed in Italy, July 2017

European University Institute

Badia Fiesolana

I - 50014 San Domenico di Fiesole (FI)

Italy

www.eui.eu/RSCAS/Publications/

www.eui.eu

cadmus.eui.eu 


\section{Robert Schuman Centre for Advanced Studies}

The Robert Schuman Centre for Advanced Studies (RSCAS), created in 1992 and directed by Professor Brigid Laffan, aims to develop inter-disciplinary and comparative research and to promote work on the major issues facing the process of integration and European society.

The Centre is home to a large post-doctoral programme and hosts major research programmes and projects, and a range of working groups and ad hoc initiatives. The research agenda is organised around a set of core themes and is continuously evolving, reflecting the changing agenda of European integration and the expanding membership of the European Union.

Details of the research of the Centre can be found on:

http://www.eui.eu/RSCAS/Research/

Research publications take the form of Working Papers, Policy Papers, Policy Briefs, Distinguished Lectures, Research Project Reports and Books.

Most of these are also available on the RSCAS website:

http://www.eui.eu/RSCAS/Publications/

The EUI and the RSCAS are not responsible for the opinion expressed by the author(s).

\section{The Global Governance Programme at the EUI}

The Global Governance Programme is one of the flagship programmes of the Robert Schuman Centre for Advanced Studies at the European University Institute (EUI). It aims to: build a community of outstanding professors and scholars, produce high quality research and, engage with the world of practice through policy dialogue. At the Global Governance Programme, established and early career scholars research, write on and discuss, within and beyond academia, issues of global governance, focussing on four broad and interdisciplinary areas: European, Transnational and Global Governance; Global Economics; Europe in the World; and Cultural Pluralism.

The Programme also aims to contribute to the fostering of present and future generations of policy and decision makers through its unique executive training programme, the Academy of Global Governance, where theory and "real world" experience meet. At the Academy, executives, policy makers, diplomats, officials, private sector professionals and academics, have the opportunity to meet, share views and debate with leading academics, top-level officials, heads of international organisations and senior executives, on topical issues relating to governance.

For more information: http://globalgovernanceprogramme.eui.eu 



\title{
Services Input Intensity and US Manufacturing Employment Responses to the China Shock*
}

\author{
Omar Bamieh $^{\dagger} \quad$ Matteo Fiorini ${ }^{\ddagger} \quad$ Bernard Hoekman ${ }^{\S} \quad$ Adam Jakubik $^{\mathbb{I}}$
}

July 21, 2017

\begin{abstract}
We present evidence that the negative effect of the China shock on US manufacturing employment is lower for industries that use services inputs more intensively. Different potential mechanisms for this finding are analyzed. This reveals significant heterogeneity across different types of services and their potential role in affecting labor demand and supply responses to greater import competition.
\end{abstract}

Keywords: Manufacturing employment, China shock, import competition, servicification, services inputs use

JEL Classification: F16; L8

\section{Introduction}

The rapid rise in China's share of global trade since the early 1990s has generated significant adjustment pressures in countries around the world. Recent research on the impact of the steep rise in exports of manufactures from China to the United States on US manufacturing employment has documented the regionally differentiated effects of the "China shock" (Autor et al., 2013, 2016). Of particular note is the finding that the negative effects on manufacturing employment in local labor markets (commuting zones) are substantial and that in the time period investigated other economic sectors within commuting zones do not provide alternative

\footnotetext{
${ }^{*}$ The authors are grateful to Andrea Ariu, Caroline Freund, Lorenzo Caliendo, Jeff Frieden, Doug Nelson, Marco Sanfilippo, Asha Sundaram; participants in the 2017 conference "The Economics \& Politics of Globalization" in New Orleans; and members of the Galbino Project for helpful comments and suggestions on presentations of initial results.

${ }^{\dagger}$ Department of Economics, European University Institute.

${ }^{\ddagger}$ Global Governance Programme, Robert Schuman Centre for Advanced Studies (European University Institute).

${ }^{\S}$ Global Governance Programme, Robert Schuman Centre for Advanced Studies (European University Institute) and CEPR.

${ }^{\mathbb{I}}$ WTO and Department of Economics, European University Institute.
} 
employment opportunities to affected manufacturing workers (Acemoglu et al., 2016), implying that much of the adjustment to the shock takes the form of exit from the labor market.

The United States is a services economy. Aggregate employment and productivity growth in the US and other high-income advanced economies is increasingly intertwined with the performance of the service sector. The share of manufacturing in total employment has been falling since the late 1970s, with a concomitant steady increase in the services content of production, consumption and employment. At the level of the economy as a whole, competition from China and other emerging economies is just one, albeit important, factor inducing shifts in employment away from manufacturing and towards services sectors. These shifts in US comparative advantage are driven by technical change and investment responses to policies in both the US and in the rest of the world (China). Services account for an increasing share of US exports (34 percent in 2016, up from 27 percent in 2000); in 2016 the services trade balance registered a surplus of $\$ 248$ billion, compared to a merchandise trade deficit of $\$ 752$ billion. ${ }^{1}$ US comparative advantage in services reflects human capital endowments and the ability to take advantage of services agglomeration externalities (Gervais and Jensen, 2014).

These broader features of structural transformation of the US economy are important in assessing the determinants of the impact of the China shock. In this paper we focus on one specific dimension of the 'servicification' of the US economy: the role of cross-sectoral variation in services input use (arms-length purchases of services) by manufacturing sectors as a factor influencing the resilience of the latter to greater import competition from China. Services such as transport, telecommunications and financial intermediation are intermediate inputs for manufacturing sectors and their cost and quality will have an impact on the productivity of manufacturing industries that use such services (see for instance Barone and Cingano, 2011; Bourlès et al., 2013; Beverelli et al., 2017). Given that the US has a revealed comparative advantage in services, downstream industries that are relatively intensive users of services in which the US has a comparative advantage may be better able to withstand import competition from China because the associated embodied services increase the quality or otherwise help to differentiate the goods that are produced.

What is of specific interest in this regard is the role of producer services such as R\&D, management consulting, engineering, supply chain logistics, and business process outsourcing as intermediate inputs into the output of manufacturing industries. Such business services support (are associated with) outsourcing of tasks and activities, which can improve manufacturing firms' productivity and thus help them to meet competitive pressures from imports and attenuate the downward shift in labor demand following a trade shock. Conversely, the intensity with which business or producer services are used as part of processes of outsourcing service activities to specialized providers may enhance the operational flexibility of manufacturing industries, resulting in greater sensitivity of manufacturing employment to trade shocks by increasing the elasticity of labor supply for the industries concerned.

\footnotetext{
${ }^{1}$ Data are from US Bureau of the Census, at https://www.census.gov/foreigntrade/statistics/historical/index.html and reflect balance-of-payments figures. Thus they do not include services sold by foreign affiliates of US multinationals, which are an important additional channel for international provision of services by US-owned companies (Francois and Hoekman, 2010).
} 
In this paper we analyze the heterogeneity of local manufacturing employment effects of the China shock, focusing specifically on the question whether differences in the intensity of use of externally purchased services inputs across US manufacturing industries is associated with greater resilience of employment to import competition from China. We use the empirical approach developed by Autor et al. (2013) to identify the employment response of manufacturing sectors at the commuting zone level in the US and distinguish between two mechanisms that affect employment effects: (1) the role that greater services intensity may play in attenuating reductions in the demand for labor following a trade shock and (2) the role that services intensity may play by increasing the elasticity of labor supply for a manufacturing sector. In the Autor et al. (2013) framework it is assumed that workers are immobile across different zones. Thus, the analysis centers on the short-run employment effects of a shock, with reallocation of factors being limited to intra-zone dynamics. Considering local labor markets to be an independent unit of analysis that is not connected to the rest of the economy permits the use of a partial equilibrium framework and a focus on local employment effects and local labor market adjustment. We do not take a stance on whether it is appropriate to limit analysis of Chinese competition to a relatively shortrun setting in which worker mobility is assumed to be very limited. Our goal is simply to deepen the understanding of the factors that determine the cross-sectoral variation in employment effects at the level of local labor markets (commuting zones) by investigating the relationship between the intensity of services input use and manufacturing industries' employment responses to trade shocks. We find that more intensive use ('outsourcing') of producer services appears to be positively associated with resilience to greater import competition.

Our analysis extends the literature in several respects. The main contribution is to assess the role of services input intensity as a determinant of the local manufacturing employment response to greater import penetration. We complement Acemoglu et al. (2016) by showing that labor demand impacts within a commuting zone is a function of the degree of sectoral exposure to Chinese imports, but that the services intensity of production is an additional factor that should be considered. We also complement Magyari (2017), who shows that at the firm level, trade with China generates cost savings which enables expansion of employment in manufacturing sectors in which the US has a comparative advantage relative to China, even as specific establishments shrink. She finds that the firms hire more services workers that are complementary to highskilled and high-tech manufacturing. More generally, our paper contributes to the debate on the employment effect of services outsourcing and offshoring. The literature has identified different theoretical channels with ambiguous predictions regarding the effects of services outsourcing on employment. ${ }^{2}$ To the best of our knowledge the role of services outsourcing on the response of manufacturing employment to trade shocks has not been investigated.

The remainder of the paper is organized as follows. Section 2 discusses the economic rationale

\footnotetext{
${ }^{2}$ On the one hand, offshoring lowers input prices and increases profits, in turn potentially increasing manufacturing production and labor demand. On the other hand, higher quality and cheaper service inputs may substitute for labor used in production, leading to a decrease in labor demand (Amiti and Wei, 2006; Milberg and Winkler, 2010b and Winkler, 2010). Consistent with the theoretical ambiguity, the results of empirical analyses are mixed (see Amiti and Wei, 2005, 2006; Schöller, 2007; Winkler, 2010; Michel and Rycx, 2012; Milberg and Winkler, 2010a, 2015). Services offshoring tends to be associated with higher demand for skilled labor at the firm-level (Crinò, 2010; Andersson et al., 2016).
} 
for focusing on the intensity of services input use in assessments of labor market adjustment following a trade shock, as well as the related literature on services as a driver of productivity and performance at the industry level. Section 3 presents the econometric framework. Results are reported and discussed in Section 4. Section 5 concludes with some implications for further work.

\section{Services input use, manufacturing employment, and trade shocks}

Autor et al. (2013) find that a local labor market's degree of exposure to imports of goods from China has a negative effect on the size of its manufacturing sector relative to geographic areas that are less exposed to imports. In what follows we hypothesise that the services input intensity of an industry will affect its response to changes in local trade exposure, i.e., for a given level of local labor market exposure to imports of manufactured goods, industries within that local labor market that are more intensive users of services are less affected.

Figure 1 ranks US manufacturing sectors (denoted with their two-digit ISIC Rev. 3 codes) in terms of their services input intensity as defined by the sum of technical input-output coefficients for six services sectors that are particularly salient intermediate inputs into production (so called 'producer services'). ${ }^{3}$ The pattern of services input intensity is relatively heterogeneous across manufacturing sectors. Transport, business and financial services tend to be relatively significant for most manufacturing industries. Conversely, R\&D services tend to be small or absent in the input consumption bundle of downstream sectors, with the notable exception of medical, precision and optical instruments (ISIC sector 33).

Various (related) mechanisms motivate the hypothesis that the effects of local exposure to import competition on employment will be heterogeneous across manufacturing sectors as a function of their services input intensity.

One is that more services intensive industries are likely to include more firms that are integrated into global value chains (GVCs). GVC participation requires many services inputs, ranging from transport and logistics to communications (Baldwin, 2016). Firms that participate in GVCs are more productive on average than firms that do not (Constantinescu et al., 2017). Greater services input intensity implies greater specialization, as the tasks and activities that are outsourced allow firms to concentrate on core areas of competitive advantage, while sourcing services from the most efficient providers in the market. This may be reflected in production of more sophisticated, higher quality, and brand differentiated products that compete less directly on price with Chinese imports. Higher services input intensity is likely to reflect greater investment in $R \& D$, product development, innovation, and marketing, helping firms to compete with foreign firms both in

\footnotetext{
${ }^{3}$ Technical coefficients in Figure 1 capture the technical relationship between US industries as of the early 1990s. Formally, technical coefficients are the elements of the square matrix $A$ defined as $A \equiv Y M$ where $Y$ is a dimension $n$ square matrix of zeros, except along the main diagonal, that includes the inverse output of each industry and $M$ is the intermediate demand matrix. For each services-manufacturing sector pair $(s, j)$, the technical coefficient is the element $a_{s j}$ of $A$ and represents the cost of the intermediate inputs from services sector $s$ per dollar of total production of manufacturing sector $j$.
} 
Figure 1: Services input intensity in manufacturing sectors

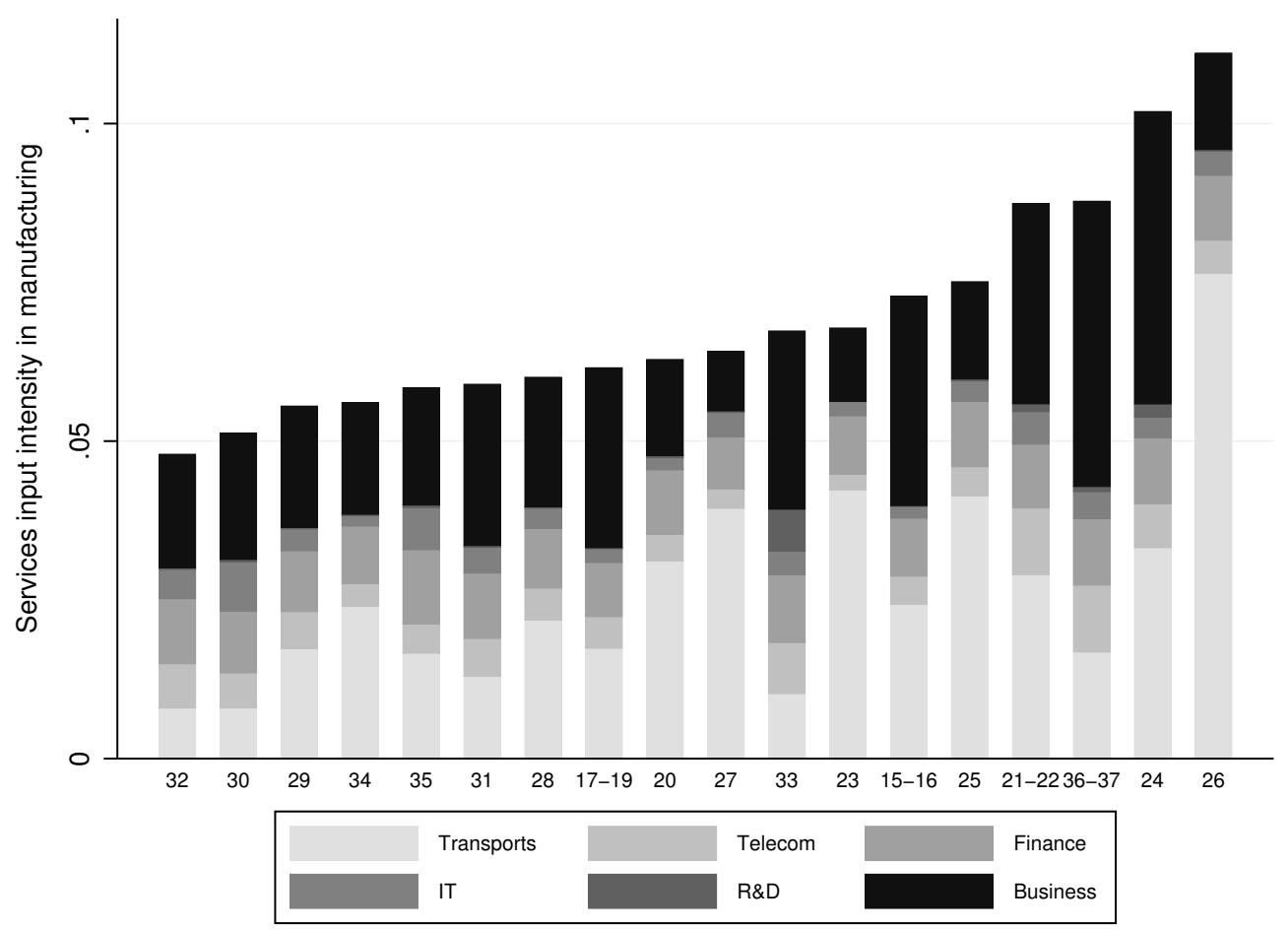

Notes: Manufacturing sectors are denoted on the horizontal axis with their 2 digit ISIC Rev. 3 codes. The mapping between sectors codes and labels is as follows. 15-16: food products, beverages and tobacco; 17-19: textiles, textile products, leather and footwear; 20: wood and products of wood and cork; 21-22: pulp, paper, paper products, printing and publishing; 23: coke, refined petroleum products and nuclear fuel; 24: Chemicals and chemical products; 25: rubber and plastics products; 26: other non-metallic mineral products; 27: basic metals; 28: fabricated metal products except machinery and equipment; 29: machinery and equipment n.e.c; 30: office, accounting and computing machinery; 31: electrical machinery and apparatus n.e.c; 32: radio, television and communication equipment; 33: medical, precision and optical instruments; 34: motor vehicles, trailers and semi-trailers; 35: other transport equipment; 36-37: manufacturing n.e.c. and recycling. For each services sector the vertical axis reports its technical coefficient in the respective manufacturing sector. Technical coefficients are computed from the earliest observation of the US input-output table sourced from the OECD IO STAN capturing the technical relationship between industries prevailing at the beginning of the 1990s.

terms of satisfying market demand and anticipating trends in consumer preferences (see Bloom et al., 2016).

The importance of services input use and associated outsourcing as a channel to boost the performance of manufacturing sectors is not new to the literature. Services outsourcing as a driver of firm performance has been the subject of numerous papers, with research identifying a positive effect of services outsourcing (and offshoring) on productivity at both the firm level (see for instance Görg et al., 2008; Hijzen et al., 2010) and at the sector level (see Amiti and Wei, 2009; Winkler, 2010). For example, Görg and Hanley (2011) identify a positive impact of (international) outsourcing of services on innovation practices in a sample of Irish manufacturing firms. The use of ICT services in a broad range of industries has been a driver of US output and productivity growth since the mid-1990s (van Ark et al., 2008).

Services play a more complex role as intermediate inputs into production than sourcing of manufactured parts and components from specialized suppliers. A key property of services inputs is the role they play in coordinating and controlling economic activities and supporting the process 
of specialization. For instance, information and communications, transport and logistics services are needed to connect labor and/or capital units across space; financial and insurance services allow firms to manage the risks of routine operations as well as risks inherent in innovation and experimentation. As "facilitators" of geographically fragmented production processes, the quality and cost of a variety of "margin" services directly influence the feasible degree of specialization and scale of downstream economic activities (Francois, 1990; Francois and Hoekman, 2010). In a world of GVCs where production involves the coordination across space and time of intermediate inputs produced by firms located in different regions or countries, this coordination function is particularly important. Baldwin et al. (2015) note that transport, telecommunications, logistics and distribution services account for an increasing share of total value added in manufacturing because of the increasing fragmentation of the production process and outsourcing of non-core activities. In the increasingly complex value chains that characterise modern manufacturing, parts have to be shipped and activities coordinated in ways that minimize the need for (cost of) storage. $^{4}$

The coordination and 'connectivity' functions provided by many of the services purchased by businesses apply irrespective whether services are performed in-house or outsourced to the market (both domestic and international). Our analysis uses US Input Output tables to capture the intensity of services input use and thus we are unable to capture the value of services that are performed in-house by firms. While this limitation biases downward our measure of the servicesintensity of production, there is a well-established and long-standing trend toward outsourcing of services functions and activities, and thus a concomitant reduction in the share of services provided in-house. ${ }^{5}$

Differences across manufacturing sectors in services input intensity in part reflect differences in the ability/willingness of industries to outsource services intermediates. An increasing use of services is part and parcel of the general pattern of the "servicification"6 of manufacturing in high-income countries (Miroudot and Cadestin, 2017). ${ }^{7}$ Recent research has highlighted the positive effects of selling services alongside manufactured products: servicification is associated with better production technology features (Crozet and Milet, forthcoming) as well as stronger export performance (Ariu et al., 2017) for manufacturing firms. Servicification may also reflect a strategy of diversification and differentiation: a good with services embedded or attached to it is different from the good by itself.

\footnotetext{
${ }^{4}$ Berlingieri (2015) finds that firms increase their services input intensity in order to manage coordination complexity (proxied by the number of contested export destination markets).

${ }^{5}$ Mancher (2014) presents data from a survey finding that a high share of manufacturing firms outsource many of the services they need to operate, including financial, legal, facilities management, human resources, customer relations and IT services.

${ }^{6}$ The term servicification is generally used to describe a shift by firms/industries in non-services sectors to perform and sell services as part of their output, with an increasing share of their revenues coming from the provision of services to clients.

${ }^{7}$ Evidence of this pattern is presented in Bernard et al. (2017) for the case of Danish firms, many of which have undergone a shift from manufacturing into services sectors by abandoning actual production but retaining many of their manufacturing-related services activities such as design and distribution. These authors find higher employment and a larger share of high-tech workers in firms that 'switch' sectors. Similar patterns are highlighted in Dauth et al. (2017) for the case of Germany, where labor transition from manufacturing to services occurs via unemployment spells and through young workers entering the labor market.
} 


\subsection{Services input use in a labor supply and demand framework}

Although the literature has found that the performance (productivity) of services industries is important for manufacturing performance; that services productivity tends to grow at a rate that is lower but not that much different from that of other sectors of the economy (Young, 2014); and that outsourcing of services by manufacturing industries is a factor driving the reduction in manufacturing employment (Schettkat and Yocarini, 2006; De Backer et al., 2015) we are not aware of research on the effects of differences in services input intensity (outsourcing) on labor demand and supply responses for manufacturing sectors following a major trade shock.

Given the partial equilibrium model that is implicit in the framework used by Autor et al. (2013) (reflected in the assumption there is no factor mobility between US commuting zones), a basic supply and demand framework suggests there will be two mechanisms through which services outsourcing may affect the response of a manufacturing firm to increased import competition. The first is the impact on labor demand as plotted in Figure 2a. Given that the trade shock will displace some demand for the output of the domestic firm, there will be an associated downward shift in the labor demand schedule (from $D$ to $D^{\prime}$ ). In industries with higher services input intensity this downward shift may be attenuated insofar as consumer demand for the domestic product is less affected (shift from $D$ to $D_{S I I}$ ). This may be due to greater ability to compete on price or to product differentiation along the vertical or horizontal dimension. If the downward shift in labor demand is mitigated, greater services input use (intensity) helps to cushion the employment effects of the trade shock.

Figure 2: Labor supply and demand framework

(a) SII affecting the labor demand shift

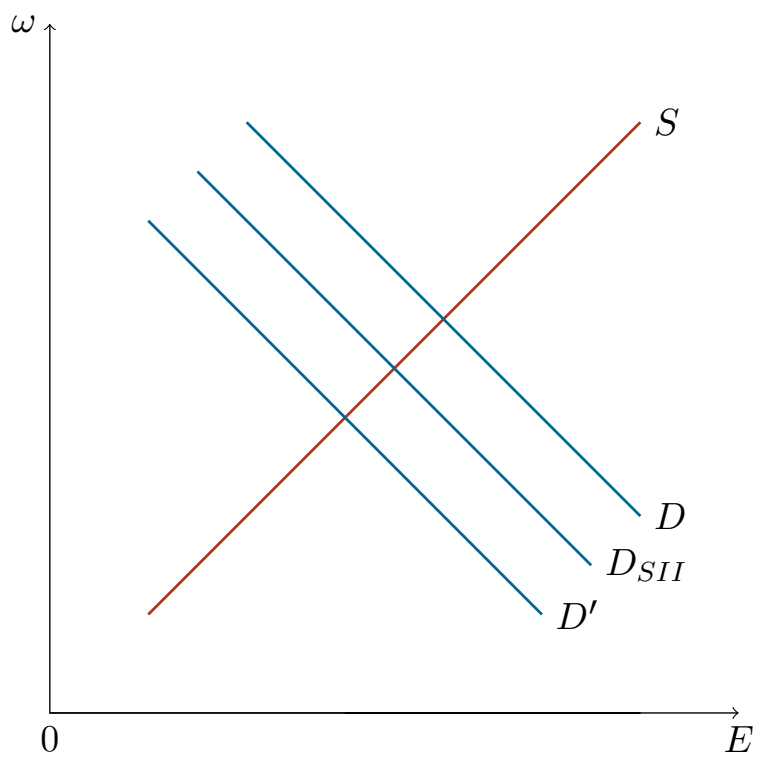

(b) SII affecting labor supply elasticity

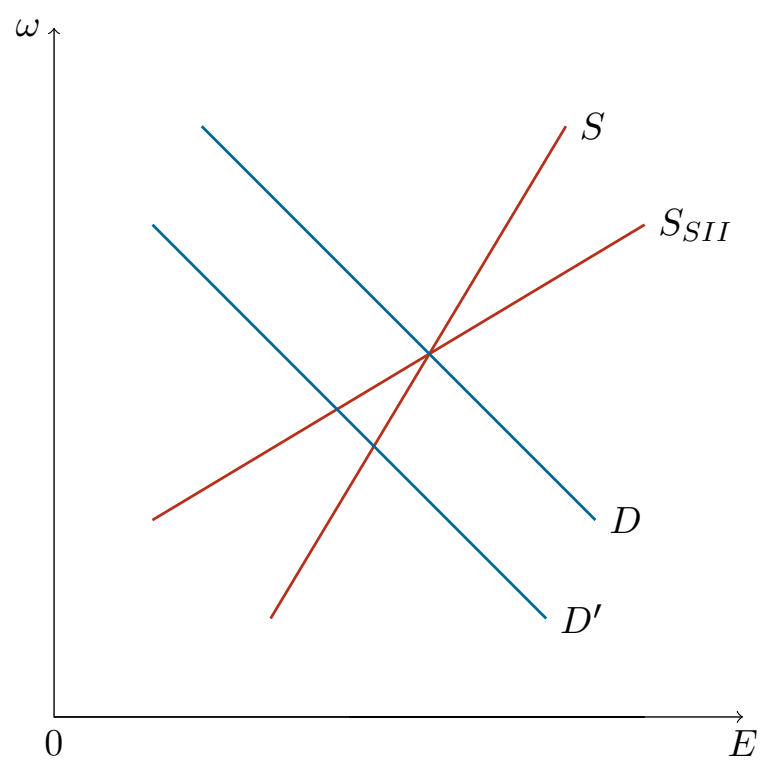

The second mechanism works on the supply side (Figure 2b). Higher services input intensity may increase the elasticity of supply of labor and thus exacerbate the employment effects of a given trade shock. The aggregate labor supply elasticity in a sector is higher when there are 
fewer barriers and fixed costs to employment, e.g. training, educational attainment, certification, firm or sector specific experience. It is also the case when a sector has a larger pool of potential workers to draw from, which may also be due to their geographic mobility or the ability to work remotely. Business and IT services in particular facilitate the outsourcing of tasks at manufacturing firms which require relatively little firm or industry specific skills. These workers will have contracts with other companies that will manage personnel-related issues, training and certification costs and contract workers at remote sites. Because there is a large market for such workers spanning many industries, they have relatively more employment opportunities than workers who are directly employed by manufacturing firms and perform tasks which require a high level of firm-specific knowledge capital. An implication is that the business and IT services input intensity of a sector is associated with a more wage sensitive labor force. The upshot is a higher labor supply elasticity, so that a given downward shift in demand will result in a greater decrease in employment by manufacturing establishments in equilibrium.

If both mechanisms are active, the net effect of a $S I I$ in shaping the employment response to a trade shock is ambiguous. It is an empirical matter which of these mechanisms dominates. ${ }^{8} \mathrm{We}$ provide an analysis of this question in Section 4.

\section{Econometric framework}

We focus on the role of services input intensity in moderating the local labor market effects of exposure to imports of manufactured goods from China as assessed in the empirical framework developed by Autor et al. (2013). We do so by augmenting their empirical specification with a sectoral dimension in the spirit of Acemoglu et al. (2016). This allows us to explicitly introduce a measure of services input intensity which is used as a moderator of the effect of the treatment variable.

\subsection{Empirical specification}

To investigate the role of differences in services input intensity in moderating the impacts of an increase in import competition on manufacturing employment, we interact the change in import exposure at the commuting zone (CZ) level with a measure of services input intensity across sectors: ${ }^{9}$

$$
\Delta E_{i s t}=\delta_{s t}+\beta \Delta I P_{i t}+\mu\left(\Delta I P_{i t} \times S I I_{s}\right)+\gamma^{\prime} \mathbf{X}_{i s t-1}+\epsilon_{i s t} .
$$

where $\Delta E_{i s t}$ is the change in employment of sector $s$ in CZ $i$ at time $t$, expressed in percentage points of working-age population, $\Delta I P_{i t}$ is the change in import penetration (exposure) to

\footnotetext{
${ }^{8} \mathrm{~A}$ detailed discussion and empirical test of role of $S I I$ in moderating the wage effect of the China shock goes beyond the scope of the present analysis and it is left for further research.

${ }^{9}$ We define local labor markets according to Autor et al. (2013) to be 722 non-overlapping commuting zones $(\mathrm{CZs})$ which represent areas with a high degree of labor mobility within and very little mobility across zones. Our empirical specification follows closely Section 6 of Acemoglu et al. (2016). We refer the reader to these papers for an in depth discussion of identification and instrumentation strategies.
} 
Chinese competition at the local labor market level as defined in Autor et al. (2013), and $S I I_{s}$ is a measure of the services input intensity of sector $s$. More precisely, $S I I_{s}$ is the manufacturing sector-specific sum over services sectors of their technical coefficients. We restrict the focus to six categories of producer services: (1) transport and storage, (2) telecommunications, (3) finance, (4) computer and related services (IT), (5) R\&D, and (6) business services. ${ }^{10}$ To rule out the possibility that the change in exposure to Chinese import competition affects the degree of service input intensity, we measure $S I I_{s}$ using data for the late 1990s, i.e. before the time period considered in the rest of the analysis. $\mathbf{X}_{i s t-1}$ is a vector of controls, including lagged variables varying at the CZ-time level and census divisions dummies interacted with sector fixed effects. ${ }^{11} \delta_{s t}$ are sector-time fixed effects, which flexibly capture any sector specific time effect. $\epsilon_{i s t}$ is the error term.

The marginal effect of changes in exposure to Chinese import competition on local employment is given by:

$$
M E_{s}=\beta+\mu \times S I I_{s} .
$$

\subsection{Data and estimation sample}

The analysis distinguishes between the two time periods analysed by Autor et al. (2013), i.e., 1990-2000 and 2000-2007, with the latter adjusted to be a 10-year equivalent. For our dependent variable, changes in sectoral employment, we use County Business Patterns (CBP) data from the U.S. Census Bureau for the years 1990, 2000 and 2007. Data on working-age population are sourced from the Population Estimates Program (PEP) of the U.S. Census Bureau. We follow Autor et al. (2013) in controlling for unobserved demand shocks affecting at the same time changes in local employment levels and Chinese import competition. We also use their instrument, an exposure variable where bilateral trade flows from China to the US are replaced by trade flows from China to a basket of other advanced economies (Australia, Denmark, Finland, Germany, Japan, New Zealand, Spain, and Switzerland). These data were made available by David Dorn. For the services input intensity measure we use US Input Output tables from the OECD STAN database for the beginning of the 1990s. Summary statistics for the main variables used in the estimation are reported in Table 1.

Table 1: Summary statistics for the main variables

\begin{tabular}{lccccc}
\hline Variable & Mean & Median & sd & Min & Max \\
\hline$\Delta E_{i s t}$ & -0.099 & -0.001 & 0.706 & -18.57 & 14.035 \\
$\Delta I P_{i t}$ & 1.906 & 1.179 & 2.582 & -0.629 & 43.085 \\
$S I I_{s}$ & 0.069 & 0.063 & 0.017 & 0.048 & 0.111 \\
\hline
\end{tabular}

\footnotetext{
${ }^{10}$ The business services category includes professional services such as legal, accounting, management consulting, and engineering.

${ }^{11}$ The 9 census divisions are identified by 8 dummies grouping together subsets of CZs.
} 


\section{Results}

Table 2 reports the results of 2SLS estimation of equation (1) using the same instruments and controls as Autor et al. (2013). This confirms at a sector-local labor market level previously known results about a negative relative effect of import exposure on employment share. We confirm that our results are invariant to progressively adding control variables capturing relevant features of the local labor markets. ${ }^{12}$ Note that we observe the effects in terms of percentage point changes, not levels, of employment share, and that the methodology permits analysis of relative effects, that is, the performance of more exposed local sector versus less exposed ones.

Table 2: Services input intensity mediates the effect of Chinese import competition

\begin{tabular}{|c|c|c|c|c|c|}
\hline \multicolumn{6}{|c|}{ Dependent variable: 10 year change in manuf empl / working-age pop (\%) } \\
\hline & (1) & $(2)$ & (3) & $(4)$ & $(5)$ \\
\hline Change in Import Exposure per worker & $\begin{array}{c}-0.107^{* * *} \\
(0.0250)\end{array}$ & $\begin{array}{c}-0.0927^{* * *} \\
(0.0279)\end{array}$ & $\begin{array}{c}-0.0875^{* * *} \\
(0.0259)\end{array}$ & $\begin{array}{c}-0.0904^{* * *} \\
(0.0261)\end{array}$ & $\begin{array}{c}-0.0918^{* * *} \\
(0.0261)\end{array}$ \\
\hline Change in Import Exposure per worker $\times S I I$ & $\begin{array}{l}0.856^{* * *} \\
(0.30195)\end{array}$ & $\begin{array}{l}0.856^{* * *} \\
(0.30195)\end{array}$ & $\begin{array}{l}0.856^{* * *} \\
(0.30197)\end{array}$ & $\begin{array}{l}0.856^{* * *} \\
(0.30196)\end{array}$ & $\begin{array}{l}0.856^{* * *} \\
(0.30198)\end{array}$ \\
\hline$\%$ Employed in Manufacturing t-1 & & $\begin{array}{c}-0.00379 * * * \\
(0.00132)\end{array}$ & $\begin{array}{c}-0.00635^{* * *} \\
(0.00123)\end{array}$ & $\begin{array}{c}-0.00505^{* * *} \\
(0.00103)\end{array}$ & $\begin{array}{c}-0.00490^{* * *} \\
(0.000991)\end{array}$ \\
\hline$\%$ College Educated $\mathrm{t}-1$ & & & $\begin{array}{c}-0.00309^{* *} \\
(0.00120)\end{array}$ & & $\begin{array}{l}-0.000702 \\
(0.000853)\end{array}$ \\
\hline$\%$ Foreign Bornt-1 & & & $\begin{array}{c}-0.00170^{* * *} \\
(0.000573)\end{array}$ & & $\begin{array}{l}0.00168^{* *} \\
(0.000698)\end{array}$ \\
\hline$\%$ Females Employed t-1 & & & $\begin{array}{l}-0.00163 \\
(0.00170)\end{array}$ & & $\begin{array}{l}0.00257^{*} \\
(0.00149)\end{array}$ \\
\hline \% Employed in Routine Occupations t-1 & & & & $\begin{array}{c}-0.0105^{* *} \\
(0.00435)\end{array}$ & $\begin{array}{c}-0.0116^{* * *} \\
(0.00430)\end{array}$ \\
\hline Average Offshorability Index t-1 & & & & $\begin{array}{c}-0.0395^{*} \\
(0.0213)\end{array}$ & $\begin{array}{c}-0.0582^{* * *} \\
(0.0194)\end{array}$ \\
\hline Observations & 25,992 & 25,992 & 25,992 & 25,992 & 25,992 \\
\hline R-squared & 0.258 & 0.264 & 0.269 & 0.272 & 0.272 \\
\hline Census division $\times$ Sector $\mathrm{FE}$ & YES & YES & YES & YES & YES \\
\hline Sector $\times$ Decade FE & YES & YES & YES & YES & YES \\
\hline
\end{tabular}

A novel finding from our analysis is the significant positive coefficient on the interaction between import exposure and services input intensity of the local manufacturing sector. This supports the hypothesis that greater use of services inputs may act to moderate adverse employment effects of an increase in import penetration. ${ }^{13}$

To illustrate this finding graphically, Figure 3 plots the marginal effect of the treatment on the dependent variable as a linear function of the moderator variable SII. The estimated marginal

\footnotetext{
${ }^{12}$ The remarkable stability of the point estimate for the coefficient of the interaction term is due to the empirical relationship between the interaction term and CZ-level controls, once conditioning for the main effect of CZ-level import penetration and all the heterogeneity embedded in the fixed effects. Indeed services input intensity only varies at the sectoral level and it is constant across CZs.

${ }^{13}$ Controling for endogeneity due to potential unobserved demand shocks using the instrumentation strategy is important as the OLS point estimates (not reported) of $\beta$ and $\mu$ are $-0.0420^{* * *}$ and $0.387^{*}$ respectively, significantly underestimating this impact.
} 
effect of exposure to manufactured imports is less negative the more the sector makes use of service inputs. For the highest values of service input use observed in the sample the effect is not statistically different from zero.

Figure 3: Marginal effect of trade shock as a function of services input intensity

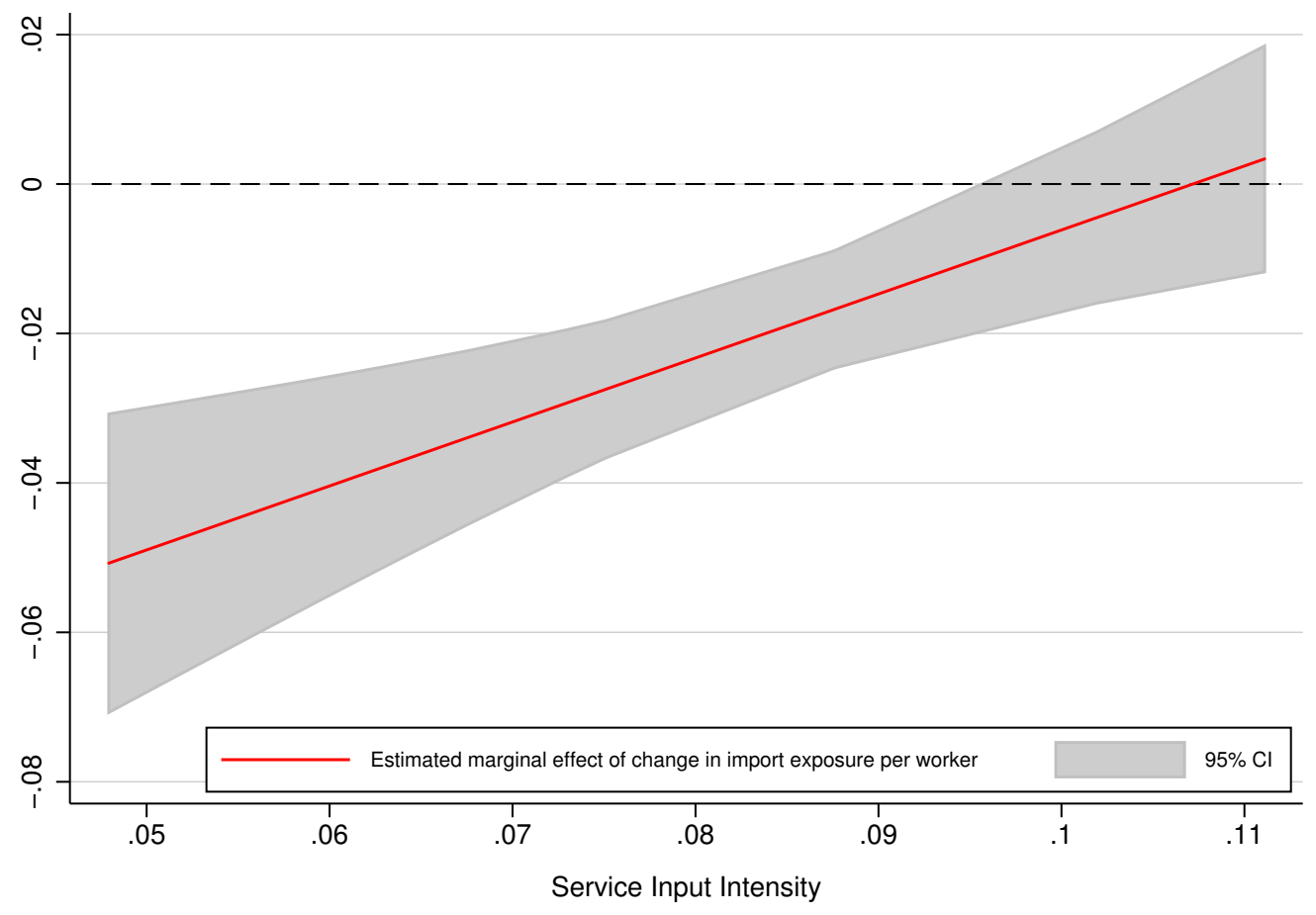

Notes: The figure shows the estimates and the corresponding $95 \%$ confidence intervals of equation (2) computed for different values of services input intensity.

The point estimates in column (5) show that, at the mean value of $S I I$ of 0.069 , a $\$ 1,000$ exogenous decadal rise in CZ's import exposure per worker reduces sectoral manufacturing employment per working-age population by approximately 0.033 percentage points $(=-.0918+0.856 \times 0.069=$ $-0.033)$. To understand the economic significance of our estimates, note that at the mean value of $\$ 1,906$ of decadal rise in import exposure, a $1 \%$ increase in import exposure leads to a reduction in sectoral manufacturing employment of $0.64 \%$, at the mean value of -0.099 of 10 -year change in the share of manufacturing employment. The same increase in import competition generates different effects depending on the sectoral SII. At the highest level of SII (0.111) the same 1\% increase in import exposure leads to an almost negligible increase of $0.06 \%$ in sectoral manufacturing employment. At the lowest level of SII (0.048), the same $1 \%$ increase in import exposure leads to a reduction in sectoral manufacturing employment of $0.98 \%$.

\subsection{Services input intensity and sectoral import exposure}

The foregoing demonstrates that services input intensity is a moderator of the China shock. SII is a "pre-treatment" sector-level characteristic of manufacturing sectors that potentially affects not only a sector's employment response to import competition but also the extent to which 
it is subject to exposure. As discussed previously, the employment effect of a trade shock will be sector-specific, depending on the degree of exposure, which is determined in part by the services intensity of different manufacturing industries. SII moderates the employment effect of the trade shock through its influence on the degree to which it attenuates the level of import competition it is confronted with, which is reflected in the magnitude of the shift of the labor demand curve across manufacturing sectors. Given the degree of sectoral exposure to import competition, services intensity may also affect a sector's response to greater import competition. This effect can operate both through a further shift in sector-specific labor demand and/or through variations across sectors in the elasticity of labor supply. In cases where labor supply is more elastic the net result may be to further reduce in labor demand.

Our empirical framework allows to precisely identify a sector's response to the China shock as long as services input intensity and sectoral import exposure are uncorrelated. In the spirit of Acemoglu et al. (2016), to guarantee exogeneity, we use predicted sectoral exposure computed by regressing US sectoral exposure on the sectoral exposure of other high-income advanced economies. As Figure 4 shows, the estimated correlation between $S I I$ and predicted sectoral exposure is negative and equal to -0.36 (see Table 3 ). This suggests that the moderating effect of $S I I$ is at least partly driven by the lower values of sectoral exposure associated with higher SII.

Table 3: Correlation between service input intensity and exposure

\begin{tabular}{lc}
\hline & Predicted Exposure \\
\hline Input intensity - all services & -0.362 \\
\hline Input intensity - transport & -0.371 \\
Input intensity - telecom & 0.115 \\
Input intensity - finance & -0.017 \\
& 0.284 \\
Input intensity - IT & 0.003 \\
Input intensity - R\&D & -0.076 \\
\hline Input intensity - business & 18 \\
\hline Observations & \\
\hline Notes: The table reports the Pearson correlation coefficient between sectoral service input intensity and sectoral expo- \\
sure. The first row refers to all service sectors, whereas each of the remaining rows refers to one of the 6 service sectors.
\end{tabular}

In order to isolate the extent to which SII determines a manufacturing sector's ability to withstand a trade shock rather than merely reduce the extent to which it is subject to import competition, we construct an alternative measure of services input intensity that is independent of sector-level import competition from China. We do this by regressing SII on sectoral exposure and using the vector of residuals, denoted as SIIres, as the moderator in our main specifica- 
Figure 4: Correlation between exposure and service input intensity

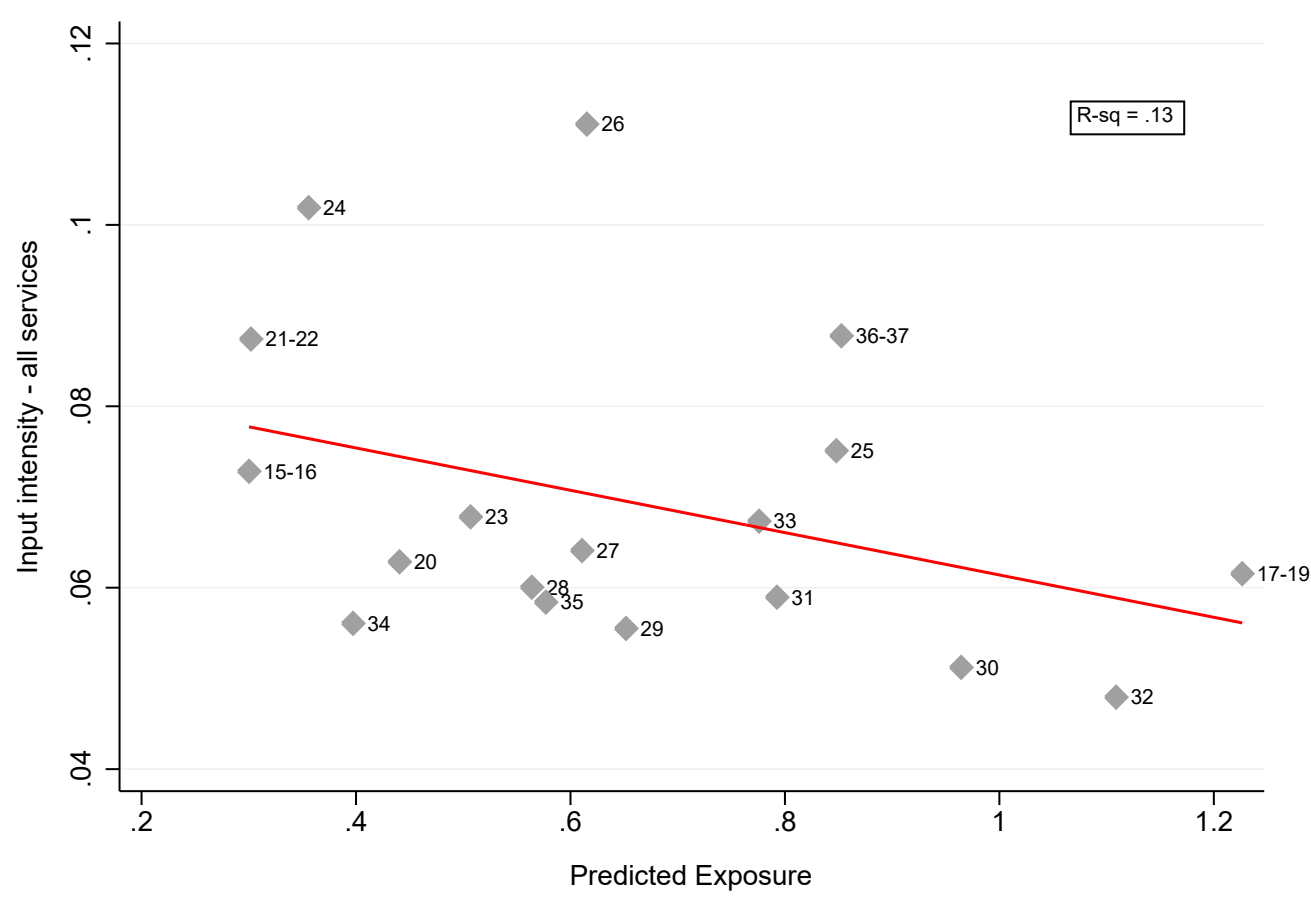

Notes: The red line shows the fitted values of the univariate regression of SII on our measure of predicted exposure. Both variables are measured at the sectoral level and manufacturing sectors are denoted with their 2 digit ISIC Rev. 3 codes. The mapping between sectors codes and labels is as follows. 15-16: food products, beverages and tobacco; 17-19: textiles, textile products, leather and footwear; 20: wood and products of wood and cork; 21-22: pulp, paper, paper products, printing and publishing; 23: coke, refined petroleum products and nuclear fuel; 24: Chemicals and chemical products; 25: rubber and plastics products; 26: other non-metallic mineral products; 27: basic metals; 28: fabricated metal products except machinery and equipment; 29: machinery and equipment n.e.c; 30: office, accounting and computing machinery; 31 : electrical machinery and apparatus n.e.c; 32: radio, television and communication equipment; 33: medical, precision and optical instruments; 34: motor vehicles, trailers and semi-trailers; 35: other transport equipment; 36-37: manufacturing n.e.c. and recycling.

tion (equation (1)). SIIres captures the portion of variability in SII which is orthogonal to sectoral import exposure. Any moderating effect of SIIres can then be attributed solely to a manufacturing sector's response to import competition and not to variation across sectors in their exposure to import competition. For ease of comparison, Column (1) of Table 4 repeats the coefficent estimate for model 5 in Table 2. Column (2) of Table 4 reports the coefficient of $\Delta I P_{i t} \times$ SIIres $_{s}$. Since the coefficient is statistically not different from zero, we conclude that the properties of $S I I$ which determine its moderating role must be embedded in the portion of its variation that co-moves with sectoral exposure. Since the properties of SII that determine the response of manufacturing sectors to import competition could well be the same ones that result in a sector being less exposed, we are unable to distinguish between the role played by SII in determining the extent of sectoral exposure to import competiton and its role in determining the response to the trade shock.

In order to further investigate this question, we unpack $S I I$ at the level of each individual producer service component, generating six different services-specific measures of input intensity, denoted as $S I I^{k}$, where $k$ is the index for different categories of producer services inputs. Figure 
Table 4: The role of service input intensity orthogonal to exposure

\begin{tabular}{|c|c|c|}
\hline & (1) & $(2)$ \\
\hline$\Delta I P_{i t} \times S I I_{s}$ & $\begin{array}{c}0.856^{* * *} \\
(0.302)\end{array}$ & \\
\hline$\Delta I P_{i t} \times$ SIIres $_{s}$ & & $\begin{array}{c}-0.397 \\
(0.396)\end{array}$ \\
\hline Observations & 25,992 & 25,992 \\
\hline
\end{tabular}

5 plots the estimated correlation between manufacturing sector import exposure and the relevant $S I I^{k}$ variable. There is substantial heterogeneity across individual services sectors. For Finance and $R \& D$ we find that the correlation is equal to 0 . In these two cases all of the moderating effect of $S I I^{k}$ (see Columns A:(5) and B:(3) of Table 5) can be attributed solely to manufacturing sectors capacity to respond to import competition.

Figure 5: Correlation between import exposure and services sector-specific SII
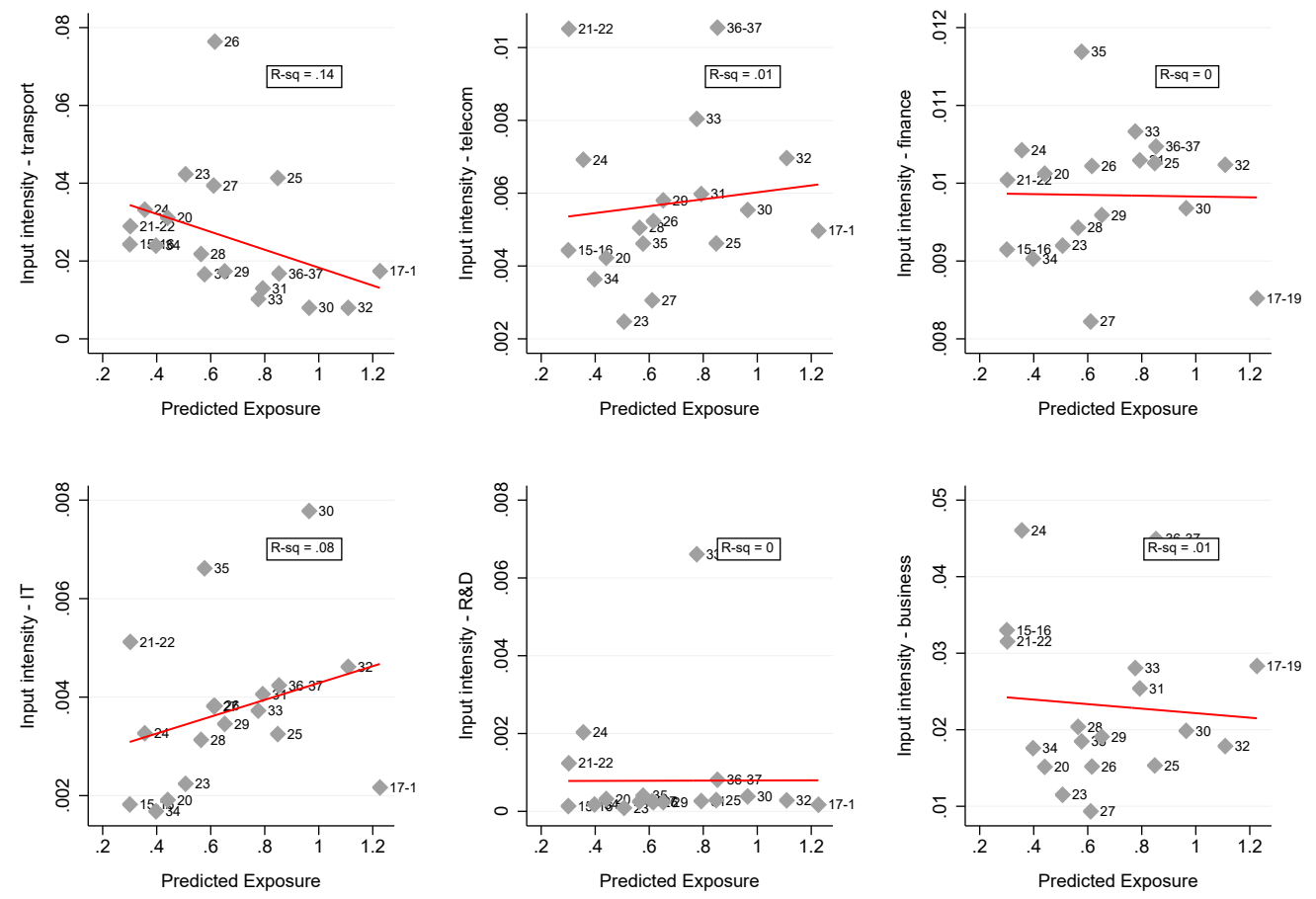

Notes: The red lines show the fitted values of the univariate regressions of $S I I$ on our measure of predicted exposure. Both variables are measured at the sectoral level and manufacturing sectors are denoted with their 2 digit ISIC Rev. 3 codes. Each graph refers to the 6 different types of services. The mapping between sectors codes and labels is as follows. 15-16: food products, beverages and tobacco; 17-19: textiles, textile products, leather and footwear; 20: wood and products of wood and cork; 21-22: pulp, paper, paper products, printing and publishing; 23: coke, refined petroleum products and nuclear fuel; 24: Chemicals and chemical products; 25: rubber and plastics products; 26: other non-metallic mineral products; 27: basic metals; 28: fabricated metal products except machinery and equipment; 29: machinery and equipment n.e.c; 30: office, accounting and computing machinery; 31: electrical machinery and apparatus n.e.c; 32: radio, television and communication equipment; 33: medical, precision and optical instruments; 34: motor vehicles, trailers and semi-trailers; 35: other transport equipment; 36-37: manufacturing n.e.c. and recycling. 
When the correlation is different from 0, we cannot distinguish between the effect of services intensity on import exposure and the effect on the employment response. For these cases, we substitute $S I I^{k}$ with $S I$ Ires $^{k}$ in the regression model in order to isolate the component of services input intensity that is orthogonal to predicted sectoral exposure. As shown in Column A:(2) the moderating properties of $S I I^{\text {Transport }}$ are completely absorbed by the portion of its variability that co-moves with sectoral exposure to imports. In this case we replicate the result obtained using the aggregate $S I I$ variable: higher services intensity reduces the negative impact on labor demand, but we cannot disentangle the mechanism through which this works. In the case of IT services, Column B:(1) reveals no statistically significant moderating effect of $S I I^{I T}$, suggesting that IT plays no role in attenuating import exposure of manufacturing sectors or the response to increased import exposure. Finally, in the case of telecommunications and business services, higher values of $S I I^{\text {Telecom }}$ and $S I I^{\text {Business }}$ are associated with larger negative employment effects of the China shock. This is consistent with a situation where the supply side (elasticity) effect augments the demand side impact, resulting in a greater decline in manufacturing employment. In the case of telecommunications, these properties are again completely absorbed by the portion of the variation that co-moves with sectoral exposure. In contrast, in the case of business services, this effect is at least partly driven by variation that is orthogonal to predicted sectoral import exposure.

Table 5: Unpacking services-specific SII effects

\begin{tabular}{|c|c|c|c|c|c|c|}
\hline \multirow[t]{2}{*}{ Panel A: } & \multicolumn{2}{|c|}{ Transport } & \multicolumn{2}{|c|}{ Telecom } & \multicolumn{2}{|c|}{ Finance } \\
\hline & (1) & (2) & (3) & (4) & (5) & (6) \\
\hline$\Delta I P_{i t} \times S I I_{s}^{k}$ & $\begin{array}{c}.463^{* * *} \\
(0.464)\end{array}$ & & $\begin{array}{c}-6.905^{*} \\
(3.919)\end{array}$ & & $\begin{array}{l}25.018^{*} \\
(14.466)\end{array}$ & \\
\hline$\Delta I P_{i t} \times S I I r e s_{s}^{k}$ & & $\begin{array}{c}0.208 \\
(0.497)\end{array}$ & & $\begin{array}{l}-3.988 \\
(3.867)\end{array}$ & & $\begin{array}{c}23.875 \\
(14.404)\end{array}$ \\
\hline \multirow[t]{2}{*}{ Panel B: } & \multicolumn{2}{|c|}{ IT } & \multicolumn{2}{|c|}{$\mathrm{R} \& \mathrm{D}$} & \multicolumn{2}{|c|}{ Business } \\
\hline & (1) & $(2)$ & $(3)$ & (4) & (5) & (6) \\
\hline$\Delta I P_{i t} \times S I I_{s}^{k}$ & $\begin{array}{l}-0.388 \\
(8.228)\end{array}$ & & $\begin{array}{l}6.365^{*} \\
(3.623)\end{array}$ & & $\begin{array}{c}-1.337^{*} \\
(0.689)\end{array}$ & \\
\hline$\Delta I P_{i t} \times S I I r e s_{s}^{k}$ & & $\begin{array}{l}10.588 \\
(9.297)\end{array}$ & & $\begin{array}{l}6.484^{*} \\
(3.630)\end{array}$ & & $\begin{array}{c}-1.768^{* *} \\
(0.737)\end{array}$ \\
\hline Observations & 25,992 & 25,992 & 25,992 & 25,992 & 25,992 & 25,992 \\
\hline $\begin{array}{l}\text { Notes: The table comp } \\
\text { moderating role of the } \\
\text { predicted exposure, } S \\
\text { service input intensity } \\
\text { the } 6 \text { service sectors } k\end{array}$ & 5 the mo & ing role & ervice in & intensity & $\begin{array}{l}I I_{s}^{k} \text {, in co } \\
\text { ained by } \\
\text { a univaria }\end{array}$ & $\begin{array}{l}\text { n }(1) \text { to the } \\
\text { variation in } \\
\text { egression of } \\
\text { rs to one of } \\
p<0.05, * *\end{array}$ \\
\hline
\end{tabular}

These results should not be over-interpreted but are nonetheless informative. They suggest there are services sector-specific differences that are masked by the finding that at the aggregate level greater services intensity is associated with a smaller decline in manufacturing labor demand (employment) following the trade shock. This aggregate result is driven by transport, finance 
and $\mathrm{R} \& \mathrm{D}$, with the last two service categories representing cases where the effect is independent of variation across manufacturing industries in exposure to import competition. Our unpacking of $S I I$ also reveals that for some types of services, business services in particular, the labor supply elasticity effect is significant: higher levels of $S I I^{\text {Business }}$ are associated with a greater decline in labor demand. These findings illustrate the need for more disaggregated analysis of the role of specific types of services as opposed to a focus on broader categories of "services inputs" or servicification of manufacturing.

\section{Conclusions}

The evidence presented in this paper suggests that services intensity is a factor differentiating local US manufacturing employment responses to the China shock. We find that the manufacturing sectors that have borne the brunt of the adjustment costs associated with import competition from China are those that are less services intensive, whereas those that use services inputs more intensively experienced less reductions in employment.

The decline in US manufacturing employment has been ongoing for decades, largely reflecting continued technological change. The share of services has expanded, reflecting a mix of interindustry productivity differences, inter-industry shifts in the division of labor (outsourcing), and increasing final demand for services as per capita incomes rise Schettkat and Yocarini (2006). Looking forward, manufacturing jobs will continue to become more skill intensive and sophisticated and be associated with further servicification of production. The implications of servicification of the economy has long been a subject of research. Less well understood is how the rise in services outsourcing (and offshoring) impacts on the employment responses of manufacturing industries to trade shocks. This paper finds that services input intensity is a factor moderating the negative employment impacts of the China shock, but also shows that it is important to "unpack" this result. Different services play different roles and functions in making manufacturing employment more or less resilient to trade shocks. This suggests that future research needs to focus on disaggregating services further and analyzing the distinct roles different services may play in influencing the employment response to greater import competition. 


\section{References}

Acemoglu, Daron, David H. Autor, David Dorn, Gordon H. Hanson, and Brendan Price, "Import Competition and the Great US Employment Sag of the 2000s," Journal of Labor Economics, 2016, 34 (S1), S141-S198.

Amiti, Mary and Shang-Jin Wei, "Fear of service outsourcing: is it justified?," Economic Policy, April 2005, 20 (42), 308-347.

_ and _ , "Service Offshoring, Productivity and Employment: Evidence from the US," CEPR Discussion Paper 5475, C.E.P.R. Discussion Papers January 2006.

_ and _ , "Service Offshoring and Productivity: Evidence from the US," World Economy, 2009, $32(2), 203-220$.

Andersson, Linda, Patrik Karpaty, and Selen Savsin, "Firm-level effects of offshoring of materials and services on relative labor demand," Review of World Economics, May 2016, 152 (2), 321-350.

Ariu, Andrea, Florian Mayneris, and Mathieu Parenti, "Providing Services to Boost Goods Exports: Theory and Evidence," mimeo 2017.

Autor, David, David Dorn, Gordon Hanson, and Kaveh Majlesi, "Importing political polarization? the electoral consequences of rising trade exposure," NBER Working Paper, 2016, 2263\%.

Autor, David H., David Dorn, and Gordon H. Hanson, "The China Syndrome: Local Labor Market Effects of Import Competition in the United States," American Economic Review, October 2013, 103 (6), 2121-68.

Baldwin, Richard, The Great Convergence: Information Technology and the New Globalization, Harvard University Press, 2016.

_, Rikard Forslid, and Tadashi Ito, "Unveiling the Evolving Sources of Value Added in Exports," Joint Research Program Series No. 161 March 2015.

Barone, Guglielmo and Federico Cingano, "Service Regulation and Growth: Evidence from OECD Countries," Economic Journal, 2011, 121 (555), 931-957.

Berlingieri, Giuseppe, "Managing Export Complexity: the Role of Service Outsourcing," CEP/LSE mimeo 2015.

Bernard, Andrew B., Valerie Smeets, and Frederic Warzynski, "Rethinking deindustrialization," Economic Policy, 2017, 32 (89), 5.

Beverelli, Cosimo, Matteo Fiorini, and Bernard Hoekman, "Services trade policy and manufacturing productivity: The role of institutions," Journal of International Economics, 2017, 104, 166 - 182. 
Bloom, Nicholas, Mirko Draca, and John Van Reenen, "Trade induced technical change? The impact of Chinese imports on innovation, IT and productivity," The Review of Economic Studies, 2016, 83 (1), 87-117.

Bourlès, Renaud, Gilbert Cette, Jimmy Lopez, Jacques Mairesse, and Giuseppe Nicoletti, "Do Product Market Regulations in Upstream Sectors Curb Productivity Growth? Panel Data Evidence for OECD Countries," Review of Economics and Statistics, December 2013, 95 (5), 1750-1768.

Constantinescu, Ileana C., Aaditya Mattoo, and Michele Ruta, "Does vertical specialization increase productivity?," Policy Research working paper; no. WPS 7978. Washington, D.C. : World Bank Group. 2017.

Crinò, Rosario, "Service Offshoring and White-Collar Employment," The Review of Economic Studies, 2010, 77 (2), 595-632.

Crozet, Matthieu and Emmanuel Milet, "Should everybody be in services? The effect of servitization on manufacturing firm performance," Journal of Economics 83 Management Strategy, forthcoming.

Dauth, Wolfgang, Sebastian Findeisen, and Jens Suedekum, "Trade and Manufacturing Jobs in Germany," American Economic Review: Papers 63 Proceedings, 2017, 107 (5), 337-342.

De Backer, Koen, Isabelle Desnoyers-James, and Laurent Moussiegt, "Manufacturing or Services - That is (not) the Question': The Role of Manufacturing and Services in OECD Economies," OECD Science, Technology and Industry Policy Papers, No. 19, OECD Publishing, Paris. 2015.

Francois, Joseph and Bernard Hoekman, "Services Trade and Policy," Journal of Economic Literature, 2010, 48 (3), 642-692.

Francois, Joseph F., "Producer Services, Scale, and the Division of Labor," Oxford Economic Papers, 1990, 42 (4), 715-729.

Gervais, Antoine and Bradford J. Jensen, "The Tradability Of Services: Geographic Concentration And Trade Costs," Working Papers 14-03, Center for Economic Studies, U.S. Census Bureau. 2014.

Görg, Holger and Aoife Hanley, "Services Outsourcing and Inoovation: an Empirical Investigation," Economic Inquiry, 2011, 49 (2), 321-333.

_ , _ , and Eric Strobl, "Productivity effects of international outsourcing: Evidence from plant level data.," Canadian Journal of Economics, 2008, 41 (2), 670-688.

Hijzen, Alexander, Tomohiko Inui, and Yasuyuki Todo, "Does Offshoring Pay? Firmlevel Evidence from Japan," Economic Inquiry, 10 2010, 48 (4), 880-895.

Magyari, Ildiko, "Firm Reorganization, Chinese Imports, and US Manufacturing Employment," mimeo, Colombia University 2017. 
Mancher, Marc, "Deloitte's 2014 global outsourcing and insourcing survey," Technical Report, Deloitte 2014.

Michel, Bernhard and François Rycx, "Does offshoring of materials and business services affect employment? Evidence from a small open economy," Applied Economics, 2012, 44 (2), 229-251.

Milberg, William and Deborah Winkler, "Economic insecurity in the new wave of globalization: offshoring and the labor share under varieties of capitalism," International Review of Applied Economics, 2010, 24 (3), 285-308.

_ and _ , "Financialisation and the dynamics of offshoring in the USA," Cambridge Journal of Economics, 2010, 34 (2), 275-293.

_ and _ , "Offshoring and the Labour Share in Germany and the US: The Role of Different Policy Regimes," World Economics, December 2015, 16 (4).

Miroudot, Sébastien and Charles Cadestin, "Services In Global Value Chains. From Inputs to Value-Creating Activities," OECD Trade Policy Papers No. 1972017.

Schettkat, Ronald and Lara Yocarini, "The shift to services employment: A review of the literature," Structural Change and Economic Dynamics, 2006, 17 (2), 127 - 147.

Schöller, Deborah, "Service Offshoring and the Demand for Less-Skilled Labor: Evidence from Germany," Hohenheimer Diskussionsbeiträge No. 287/2007 2007.

van Ark, Bart, Mary O'Mahoney, and Marcel P. Timmer, "The Productivity Gap between Europe and the United States: Trends and Causes," Journal of Economic Perspectives, March 2008, 22 (1), 25-44.

Winkler, Deborah, "Services Offshoring and its Impact on Productivity and Employment: Evidence from Germany, 1995-2006," The World Economy, December 2010, 33 (12), 16721701.

Young, Alwyn, "Structural Transformation, the Mismeasurement of Productivity Growth, and the Cost Disease of Services," American Economic Review, November 2014, 104 (11), 3635-67. 